Provided for non-commercial research and education use. Not for reproduction, distribution or commercial use.

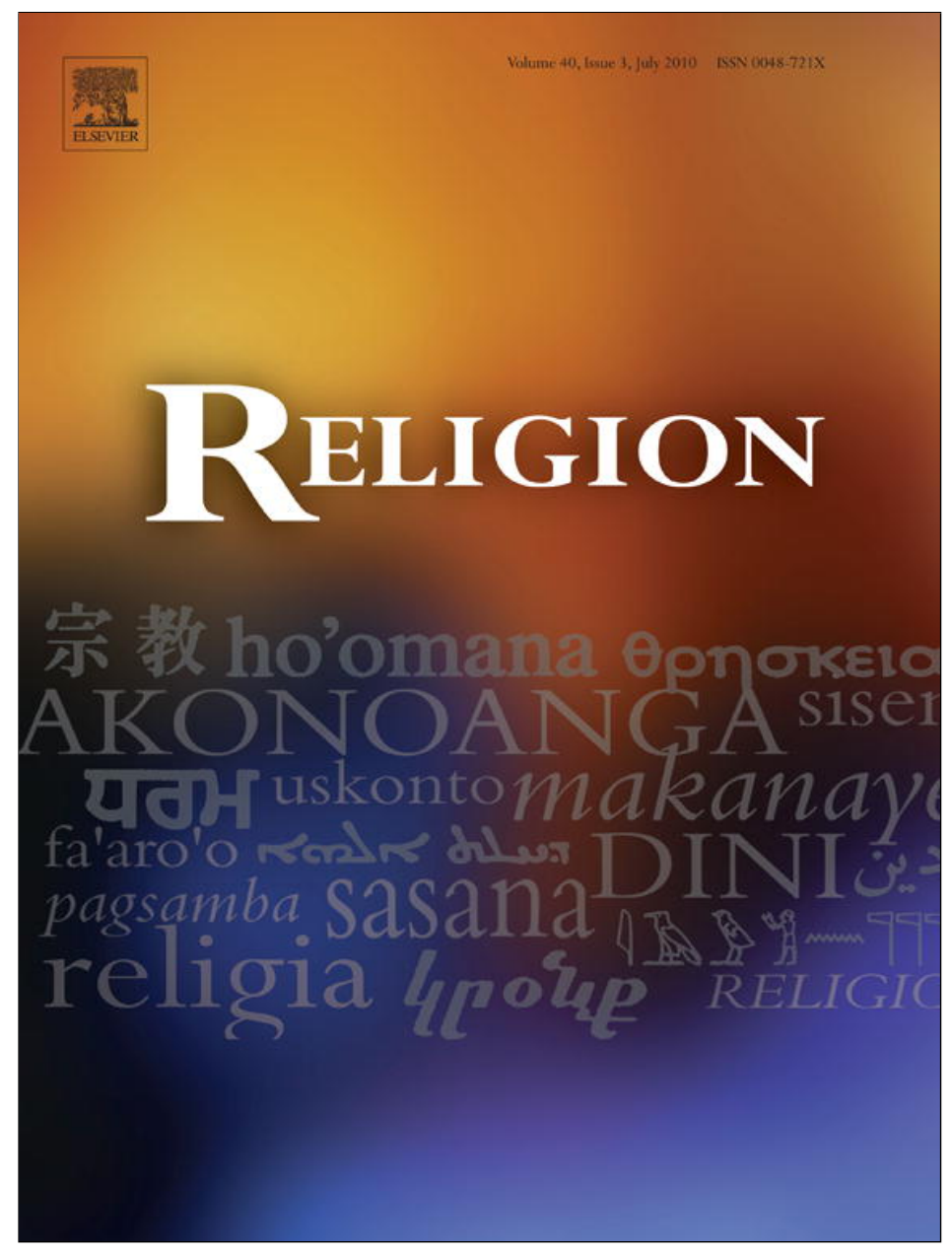

This article appeared in a journal published by Elsevier. The attached copy is furnished to the author for internal non-commercial research and education use, including for instruction at the authors institution and sharing with colleagues.

Other uses, including reproduction and distribution, or selling or licensing copies, or posting to personal, institutional or third party websites are prohibited.

In most cases authors are permitted to post their version of the article (e.g. in Word or Tex form) to their personal website or institutional repository. Authors requiring further information regarding Elsevier's archiving and manuscript policies are encouraged to visit:

http://www.elsevier.com/copyright 


\title{
Religion is natural, atheism is not: On why everybody is both right and wrong
}

\author{
Armin W. Geertz ${ }^{\mathrm{a}, *}$, Guðmundur Ingi Markússon ${ }^{\mathrm{b}}$ \\ ${ }^{a}$ Department of the Study of Religion, Aarhus University, Taasingegade 3, DK-8000 Aarhus C, Denmark \\ ${ }^{\mathrm{b}}$ Independent scholar, Reykjavik, Iceland
}

\section{A R T I C L E I N F O}

\section{Article history:}

Available online 19 February 2010

\section{Keywords:}

Atheism

Irreligion

Cognitive science of religion

Memetics

Evolution

Biology

Semiotics

Culture

Psychology of religion

\begin{abstract}
A B S T R A C T
After discussing evidence of irreligion and the rise of the so called "New Atheism", the authors refute the claim that this poses a problem for the cognitive science of religion and its hypothesis that religion is natural. The "naturalness hypothesis" is not deterministic but probabilistic and thus leaves room for atheism. This, the authors maintain, is true of both the by-product and adaptationist stances within the cognitive science of religion. In this context the authors also discuss the memetic or "unnaturalness" hypothesis, i.e. that religion is a "virus of the mind". The authors criticize accounts of atheism offered by cognitive scientists of religion as being based on unfounded assumptions about the psychology of atheists, and object to the notion that the natural aspects of religion by corollary make atheism unnatural. By considering human cognition in a semiotic framework and emphasizing its natural ability to take part in semiotic systems of signs, atheism emerges as a natural, cognitive strategy. The authors argue that to reach a fuller account of religion, the cognitive (naturalness) and memetic (unnaturalness) hypotheses of religion must be merged. Finally, a preliminary analysis of the "New Atheism" is offered in terms of semiotic and cognitive dynamics.
\end{abstract}

(C) 2009 Elsevier Ltd. All rights reserved.

\section{Introduction}

Irreligion is back on the scene not least because of the so-called New Atheism. In this context it has been claimed that irreligion constitutes a problem for the cognitive science of religion due to its emphasis on the naturalness of religion. This claim, we argue, is wrong because it is based on a misunderstanding of the cognitive approach. But accounts of atheism in the cognitive science of religion are not without fault either since these are partly informed by unsupported assumptions about the psychology of atheists. In this article, we will also consider the differences between the naturalness hypothesis and Dawkins' memetic or unnaturalness hypothesis of religion and argue that, ultimately, both approaches must be combined if we are to achieve a comprehensive account of religious and cultural systems.

\section{Irreligion}

The past few years have witnessed a burgeoning field which has been called New Atheism. ${ }^{1}$ A whole spate of books has appeared since the ground-breaking volumes by philosopher Daniel Dennett (2006) and biologist Richard Dawkins (2006). Much of the literature is

\footnotetext{
* Corresponding author. Tel.: +45894223 06; fax: +4586130490.

E-mail address: awg@teo.au.dk (A.W. Geertz).

1 Thanks to colleagues sociologist of religion Margit Warburg, Department of Cross-Cultural and Regional Studies, University of Copenhagen, Denmark and Gretchen Koch, former doctoral student at the Department of the Study of Religion, Aarhus University, Denmark for critical comments on the sections on irreligion and the New Atheism in this article. The section on ancient Indian atheism benefited immensely from discussions with historian of religions Mikael Aktor, Department of Philosophy, Education and the Study of Religion, University of Southern Denmark as well as discussions with historian of religions Marianne Qvortrup Fibiger, Department of the Study of Religion, Aarhus University. Thanks goes as well to Kirstine Helboe Johansen, former doctoral student at the Department of Church History and Practical Theology, Aarhus University for critical comments on the article as a whole. Our gratitude is extended to our anonymous reviewers whose critical comments have helped improve the article, and a special thanks to Justin Barrett and Jesse Bering for taking the time to reply to this article. Despite such gracious support from colleagues, this article is our responsibility alone.
} 
blatantly anti-religious and written as a direct attack on religion, religious influence in U.S. politics and elsewhere, and superstition and gullibility wherever it appears. There are a growing number of blogs, ${ }^{2}$ internet journals, ${ }^{3}$ and special issues of magazines on the subject of religion, science and atheism. ${ }^{4}$ Outspoken atheistic or agnostic organizations like the Council for Secular Humanism, ${ }^{5}$ the Skeptics Society, ${ }^{6}$ American Atheists ${ }^{7}$ and the Brights Movement ${ }^{8}$ have arisen in response to extremist, especially conservative Christian organizations that are constantly and systematically attempting to undermine democracy, enlightenment, education, science and public opinion in the United States in the name of religious dogma. The creationist debate and attempts to legislate creationist ideology into State school curricula is just one example of the anti-Enlightenment movement. A consistent discourse is promoted claiming that the vast majority of American citizens believe in God (a Newsweek poll claimed 91\% in 2007) and ignoring or denigrating atheists as an insignificant minority (Aronson, 2007). Other polls seem to indicate that more than 29 million American adults, or one in seven, declare themselves to be without religion (American Religious Identification Survey, 2001 gave a result of $14 \%$ ). ${ }^{9}$ The Financial Times/Harris poll of 2006 gave a result of $18 \%{ }^{10}$ The Financial Times/Harris poll also indicated that $73 \%$ in the U.S. claimed to believe in any form of God or any type of supreme being.

Figures are quite different in that poll for European countries (see Table 1). The poll suggests that in Great Britain, France and Germany, the majority are either agnostics or atheists. In Spain, agnostics and atheists are almost as numerous as believers in any form of God or any type of supreme being. In Italy, believers form a substantial majority, but still not to the extent seen in the U.S. These figures, if reliable, could indicate why Europeans generally are not as upset by the New Atheist literature as Americans are. Nevertheless, the $18 \%$ of the American population that claim to be agnostic or atheist is not insignificant. Sociologist Phil Zuckerman at Pitzer College, Claremont, California places a rough estimate, based on a survey of some 50 countries, of approximately 500-750 million people in the world who do not believe in God, which he points out would make non-belief the fourth-largest persuasion, after Christianity ( 2 billion), Islam (1.2 billion) and Hinduism ( 900 million). ${ }^{11}$

Pete Berkowitz (2007) reports impressive book sales by New Atheists. In less than 12 months over a million books have been sold. As of 2007, 500,000 hardcover copies are in print of Richard Dawkins' The God Delusion (Dawkins, 2006), 296,000 copies of Christopher Hitchen's God Is Not Great (Hitchens, 2007a), 185,000 copies of Sam Harris' Letter to a Christian Nation (Harris, 2006), ${ }^{12} 64,100$ copies of Dennett's Breaking the Spell (Dennett, 2006), and 60,000 copies of Victor J. Stenger's God: The Failed Hypothesis (Stenger, 2007). These are the main New Atheist authors, but there are also other recent publications which follow suit. ${ }^{13}$ New Atheist publications have been quickly followed by anti-atheist books, ${ }^{14}$ but do book sales indicate a change in American attitudes? Ronald Aronson, writing in The Nation (Aronson, 2007), claims that they perhaps answer the frustrations of audiences tired of the political influence that conservative Christian denominations have played in recent U.S. history, especially since the attack of September 11, 2001, but whether this indicates any major shifts in American attitudes is another question.

On that point, it should also be noted that this is not simply an intellectual movement, even though many deconverts claim that they abandoned religious belief because the intellectual price was too great. The above-mentioned agnostic and atheistic organizations as well as many other similar organizations are socially active in promoting atheism/agnosticism, helping doubters "cross the line to deconversion", fighting court battles against discrimination and against measures that are clearly against the American Constitution, and so on. An example in point is Madison, Wisconsin-based Freedom From Religion Foundation (FFRF), founded in 1976 by Annie Nicol Gaylor and her daughter Annie Laurie Gaylor. The two presidents are Annie Laurie Gaylor and her husband Dan Barker, a former Pentecostal Christian minister. They have some 12,000 members, produce podcasts such as Freethought Radio show, and a newspaper Freethought Today. The subtitle of the organization is: Protecting the Constitutional Principle of the Separation of State and Church, and they have systematically raised litigation against State and Federal use of religious symbols. Other organizations have similar activities, including college-campus groups of secular humanists, Darwin Day celebrations, youth camps, student essay contests, conventions, conferences, and summer camps for kids. The first atheist summer camp was established in 1996, called Camp Quest. It was founded by Edwin Kagin and his wife Helen. Today there are six

\footnotetext{
${ }^{2}$ ScienceBlogs is a community of scientists and other academic bloggers. One of the critics on the subject of New Atheism is Nisbet (2007a,b). See Rosenhouse (2008) for a response. See Meyers' (the biologist who was expelled from Expelled) letter to Harris (Meyers, 2007). An excellent atheism blog is AtheistPerspective: Putting Atheism, Faith, God and Religion into Perspective, available at: http://www.atheistperspective.com. The Edge. The Third Culture is a web journal put out by Edge Foundation, Inc. established in 1988 as an off-shoot of The Reality Club. It covered a seminal event hosted by The Science Network, an educational organization in California, on the topic "Beyond Belief: Science, Religion, Reason and Survival" (Salk Institute, La Jolla, November 5-7, 2006). The event featured many of the New Atheists and others interested in the subject. The talks by the speakers were made available at the Edge website. See: http://www.edge.org/3rd_culture/beyond_belief06/beyond_belief06_index.html. Note that at least three figures involved in the cognitive science of religion are among contributors to the Edge: Jesse Bering, Scott Atran and Dan Sperber.

${ }^{3}$ For a summary of some of the characters in the New Atheism movement, see Gary Wolf's article in Wired (Wolf, 2006). See also Wilson's (2007a, 2007b) critique of the New Atheists and Jonathan Haidt's critique of Hitchens (Haidt, 2007). See Dawkins' reply to Wilson (Dawkins, 2007).

4 See Adler (2006) and Rosenhouse's response (Rosenhouse, 2006). See Orr (2006), Wieseltier (2006), Berkowitz (2007), Gottlieb (2007), and Aronson (2007) for reviews. See also the debate between Daniel Dennett and Richard Swinburne (Dennett and Swinburne, 2006). Thanks to Gretchen Koch for assistance in tracking down some of the most important blogs and recent articles on the new atheists. See her interesting discussion of reactions to Dennett's book in Koch (2008).

${ }^{5}$ http://www.secularhumanism.org.

${ }^{6}$ http://www.skeptic.com.

7 http://www.atheists.org.

8 http://www.the-brights.net.

9 Barry et al. (2001, p. 13). See also http://www.gc.cuny.edu/faculty/research_briefs/aris/key_findings.htm.

10 The Harris Poll Global Omnibus, J5978 December Pan Euro 2006, Harris Interactive, A266 Financial Times - Religion. Field Period: 30 th November-15th December 2006. See also http://www.harrisinteractive.com/news/allnewsbydate.asp?NewsID=1131.

11 Zuckerman (2007, p. 55).

12 Harris' book The End of Faith (Harris, 2004) in its paperback edition (published in October 2005) entered the New York Times Best Seller list at number four, and remained on the list for a total of 33 weeks. For a detailed analysis of Dennett's and Dawkins' books, see Geertz (2008a, 2009a).

13 Cf. Shermer (1997), Eller (2004, 2007), and Mills (2006).

14 Cf. McGrath (2004, 2006), McGrath and McGrath (2007), Haught (2008), Hahn and Wiker (2008), and Aikman (2008). It should be mentioned that McGrath is a former atheist who though still sympathetic is very critical of atheism. This does not mean, however, that he is not critical of religion. McGrath argues that the "failures of imagination" and complicity with oppression often characteristic of religions are some of the causes of atheism.
} 
Table 1

Belief in god or supreme being. Q3005_1 “Thinking now about religion, would you say that you are a...?” Base: All adults in six countries.

\begin{tabular}{|c|c|c|c|c|c|c|}
\hline & $\begin{array}{l}\text { Great Britain } \\
\%\end{array}$ & France & Italy & Spain & Germany & United States \\
\hline $\begin{array}{l}\text { Believer in any form of God or any type } \\
\text { of supreme being }\end{array}$ & 35 & 27 & 62 & 48 & 41 & 73 \\
\hline $\begin{array}{l}\text { Agnostic (one who is sceptical about the existence } \\
\text { of God but not an atheist) }\end{array}$ & 35 & 32 & 20 & 30 & 25 & 14 \\
\hline Atheist (one who denies the existence of God) & 17 & 32 & 7 & 11 & 20 & 4 \\
\hline Would prefer not to say & 6 & 6 & 8 & 8 & 10 & 6 \\
\hline Not sure & 7 & 4 & 3 & 3 & 4 & 3 \\
\hline
\end{tabular}

Note: Percentages may not add up exactly to $100 \%$ due to rounding.

Camp Quests across North America (Ohio, Kentucky, Minnesota, Michigan, California in the U.S. and Ontario in Canada) and one is currently being organized in the United Kingdom. ${ }^{15}$

All more nuanced polls seem to indicate that the 20th century has seen a decline in religious belief and religious affiliation whereas there is a clear and dramatic increase in irreligion. This fact raises anew the questions that secularization theorists have been struggling with and which, many have claimed, have been disproven by the new religiosity of recent decades. The question is whether there really has been a significant increase in religiosity in the West, even in the United States. Gregory Paul and Phil Zuckerman have argued that such an increase has not occurred (Paul and Zuckerman, 2007). The only significant increase is in the adult, democratic free choice of irreligion. They argue that this is so because first nation democracies have stable, socio-economic security. The only first nation democracy that does not have a stable, socio-economic security is the United States. And this, they claim, is the reason why U.S. figures are not on the same level as European figures. In the U.S., a comfortable middle class situation can easily end in financial ruin, not least because of overwhelmingly prohibitive medical bills and no universal health care:

Rather than religion being an integral part of the American character, the main reason the United States is the only prosperous democracy that retains a high level of religious belief and activity is because we have substandard socio-economic conditions and the highest level of disparity... To put it starkly, the level of popular religion is not a spiritual matter, it is actually the result of social, political and especially economic conditions (please note we are discussing large scale, long term population trends, not individual cases). Mass rejection of the gods invariably blossoms in the context of the equally distributed prosperity and education found in almost all 1st world democracies. There are no exceptions on a national basis. That is why only disbelief has proven able to grow via democratic conversion in the benign environment of education and egalitarian prosperity. Mass faith prospers solely in the context of the comparatively primitive social, economic and educational disparities and poverty still characteristic of the 2nd and 3rd worlds and the U.S. (Paul and Zuckerman, 2007).

But, Zuckerman argues in his chapter in The Cambridge Companion to Atheism, worldwide atheism may be in decline 'due to the demographic fact that highly religious nations have the highest birth rates in the world, and highly irreligious nations have the lowest birth rates in the world' (Zuckerman, 2007, p. 59).

\section{The new atheism}

What is the New Atheism? Some argue that it differs significantly from earlier forms of atheism. ${ }^{16}$ The question is how new the New Atheism might be. Michael Martin divides atheism into two types, negative and positive:

Negative atheism in the broad sense is...the absence of belief in any god or Gods, not just the absence of belief in a personal theistic God, and negative atheism in the narrow sense is the absence of belief in a theistic God. Positive atheism in the broad sense is, in turn, disbelief in all gods, with positive atheism in the narrow sense being the disbelief in a theistic God. (Martin, 2007, p. 2)

How do the New Atheists understand themselves? Quotes from two central authors are instructive. Richard Dawkins wrote:

I shall define the God Hypothesis [as] there exists a superhuman, supernatural intelligence who deliberately designed and created the universe and everything in it, including us. This book will advocate an alternative view: any creative intelligence, of sufficient complexity to design anything, comes into existence only as the end product of an extended process of gradual evolution. Creative intelligences, being evolved, necessarily arrive late in the universe, and therefore cannot be responsible for designing it. God, in the sense defined, is a delusion; and, as later chapters will show, a pernicious delusion. (Dawkins, 2006, p. 31, Dawkins' italics).

In our view, Dawkins is not quite consistent here. He may state that he's going after the supernatural in general, but his characterization of the "God hypothesis" reveals that Dawkins has a Christian point of reference; the "god hypothesis" is clearly a creationist hypothesis. Daniel Dennett's approach is different. Unfortunately, he does not introduce his ideas on atheism systematically, but following his comments on religion here and there, we can discern his main tenets. Like Dawkins, Dennett is not rejecting a particular kind of theism, rather he rejects belief in supernatural agents in general. Dennett considers religious belief to be a considerable obstacle in attaining a consensus on questions about ultimate values in a Democratic society (Dennett, 2006, p. 14). He claims that religious beliefs should be

\footnotetext{
15 http://www.camp-quest.org.

${ }^{16}$ For instance Berkowitz (2007). For an excellent recent study of atheism, see Martin (2007). For an overview of the specifically American context of unbelief, see Turner (1985).
} 
subjected to invasive investigation so that the spell of religious belief can be broken (thus the title of his book). ${ }^{17}$ He demands that religious believers be as relentlessly self-critical as 'we skeptics' (p. 17). Dennett calls such skeptics 'brights'. Brights, according to the Brights' Net website are:

- A bright is a person who has a naturalistic worldview

- A bright's worldview is free of supernatural and mystical elements

- The ethics and actions of a bright are based on a naturalistic worldview ${ }^{18}$

\section{Atheism and claims of the naturalness of religion}

Phil Zuckerman believes that the statistics on atheism deliver a heavy blow to cognitive claims of the naturalness of religion, but we disagree. One of the reasons we claim he is wrong is that he seems to misunderstand the naturalness hypothesis. He writes, 'Its central tenet is that belief in God is biologically determined, neurologically based, or genetically inborn, growing out of the "natural" processes of the human brain' (Zuckerman, 2007, p. 60). Before going into the issue, it must be stressed that Zuckerman fuses a number of different types of the naturalness-of-religion-hypotheses in a single crucible labeled "innateness of religious belief". Thus we find references to Barrett ${ }^{19}$ (proponent of the cognitive science of religion, discussed below), Wilson ${ }^{20}$ (whose thesis is based on Darwinian group selection) along with figures associated with "neuorotheology": Michael Persinger (whose experiments have not been replicated), and Ashbrook, Albright, Newberg and d'Aquili (who all clearly have religious agendas). ${ }^{21}$ This fusion is unfortunate as these represent different, theoretical avenues. In what follows, we are only concerned with the naturalness hypothesis associated with the cognitive science of religion.

The naturalness hypothesis as widely understood by cognitive scientists of religion refers to the fact that religious ideas and behaviors thrive on (or are parasitic to) normal human cognitive and psychological processes. Cognitive anthropologist Pascal Boyer was the first to frame the naturalness-of-religion hypothesis. There are two types of naturalness, Boyer argues, the one being the subjective feeling among believers that their religious postulates are obvious and self-evident, or "natural". The second type, which Boyer is mainly interested in, concerns 'those aspects of religious ideas which depend on noncultural constraints' (Boyer, 1994, p. 3). There are also two types of constraints, according to Boyer. The first are evolutionary constraints, which consist of 'those aspects of the selective pressure that can be said to have a direct effect on the range of religious ideas and practices found in human societies' (Boyer, 1994, p. 15). The second are cognitive constraints, which consist of 'universal features of the human mind-brain, which have a direct effect on the likelihood that certain ideas will be acquired, memorized, and transmitted' (ibid.). Boyer focuses on the latter and argues persuasively that such constraints are nontrivial. Prior cognitive structures, it is argued, constrain developmental sequences that are 'triggered by experiential cues' (Boyer, 1994, p. 27). Some of these structures are 'the direct consequence of genetically constrained properties of the mind-brain', others are 'particular effects of these genetic constraints' (Boyer, 1994, p. 26).

More succinctly, the above-mentioned cognitive psychologist Justin Barrett characterizes the "naturalness-of-religion thesis" as 'much of what is typically called "religion" may be understood as the natural product of aggregated ordinary cognitive processes' (Barrett, 2000, p.29).

Thus, cognitive scientists of religion are not looking for special areas of the brain dedicated to religious thought and behavior such as the above-mentioned neurotheologians are interested in. Religious thought and behavior, according cognitive scientists of religion, is natural because it draws on naturally evolved cognitive capacities and operations.

Although Zuckerman is wrong in his claim about the cognitive science of religion, he does touch upon an important point that must be taken seriously, viz. the fact of atheism in the face of the naturalness hypothesis. If religion is natural, whence the spread of non-belief? Dealing with this question is instructive, illustrating as it does the implications of cognitive approaches to religion.

\section{The unnaturalness and naturalness hypotheses}

Zuckerman's stance is in keeping with an attitude that seems common among New Atheists, many of whom seem averse to any idea of naturalness when it comes to religion. Already beginning in his original chapter on the meme concept in The Selfish Gene (Dawkins, 1976) and later developed in other writings, Richard Dawkins offered what could be called an "unnaturalness hypothesis" where religion does not depend on normal human cognitive and psychological processes but on an external "mind virus". In this account, the pristine minds of children are subject to hostile takeover by religious ideas, i.e. viral memes that are transmitted by parents to children:

When you [a child] are preprogrammed to absorb useful information at high rate, it is hard to shut out pernicious or damaging information at the same time. With so many mindbytes to be downloaded... it is no wonder that child brains are gullible, open to almost any suggestion, vulnerable to subversion, easy prey to Moonies, scientologists and nuns. Like immune-deficient patients, children are wide open to mental infections that adults might brush off without effort (Dawkins, 1993, p. 13f).

Dawkins repeats this argument in his 2006 book The God Delusion. He argues that the child cannot distinguish between the truth values of 'Don't paddle in the crocodile-infested Limpopo' and 'You must sacrifice a goat at the time of the full moon, otherwise the rains will fail' (Dawkins, 2006, p. 176). Both come from respected authorities and are given as serious commands by which obedience is expected:

The same goes for propositions about the world, about the cosmos, about morality and about human nature. And, very likely, when the child grows up and has children of her own, she will naturally pass the whole lot on to her own children - nonsense as well as sense using the same infectious gravitas of manner (p. 176).

\footnotetext{
${ }^{17}$ Apropos discussions later in this article, see Justin Barrett's refutation of Breaking the Spell (Barrett, 2007).

18 http://the-brights.net.

19 Barrett (2004).

20 Wilson (2002)

21 For a critical analysis of neurotheology, see Geertz (2009b).
} 
One can understand why atheistic activists feel more at ease with the unnaturalness hypothesis than its natural alternative. The notion of religion as a transmitted, mental illness fits hand-in-glove with the ideological aspects of the New Atheist movement. Not only is religion unnatural (and by association atheism natural), it is also a condition that is treatable, at least in principle. ${ }^{22}$

The weakness of the unnaturalness hypothesis as an explanation of the origins and persistence of religion lies in the fact that it cannot explain its universal or recurrent aspects (e.g. the centrality of such things as supernatural agents, certain types of rituals, and so on). If religion depends on the gullibility of children, in the sense that they will believe and copy anything they are told by their elders, we should expect to find much more variation in the cultural complexes we call religions (Markússon, 2007). It is precisely here that the strength of the cognitive science of religion comes to light. The naturalness hypothesis accounts for a range of recurrent issues quite economically. For example: a) why religion is a human universal, being present in all known human groups (the human mind-brain is more or less the same everywhere); b) why supernatural agents are central to most religious systems (they activate entrenched cognitive mechanisms such as our hyperactive agency detection and are easy to process and memorize); and c) why rituals take the form that they do (due to action representation and effects on memory). The unnaturalness hypothesis, on the other hand, explains at best surface variation (say, why an important agent is called "Jesus" here but "Visnu" there) and the propagation of superstitious beliefs (Markússon, 2007).

However, we still maintain that Dawkins' unnaturalness hypothesis identifies important aspects of cultural transmission and that a full account of religion will have to combine both approaches. We will return to this issue below.

\section{The naturalness hypothesis and the fact of atheism}

One does not need to stray far on the internet to find debates on religion between New Atheists and apologists of religion. In such debates one may read such proclamations as 'children are born without religion' (implying that non-religiosity is their natural state) or, from apologists of religion, that 'religion is an existential necessity for humans'. The problem with debating with New Atheists and religious apologists is that the discussion quickly gets bogged down in polemical crossfire. There's little room for more nuanced positions. If you haven't dug your own trench, one will be dug for you. But do these opposite positions make sense, and is the cognitive science of religion with its naturalness hypothesis on the side of religious apologists, as Zuckerman seems to suggest? The answer to both questions is 'No'.

From the vantage point of the cognitive science of religion, religion is neither a "hardwired" existential necessity nor is it an example of cultural "mental illness". A little thought experiment might help here. A group of infants find themselves on an uninhabited island where they grow up to form a social group in the absence of parental guidance. Will they grow up to be religious or not? The unnaturalness account would answer 'No'. There is no one to impart a religious tradition, no carrier of the "virus of the mind" called religion. The naturalness account would answer not an unequivocal 'Yes', but a qualified 'Most likely'. The island's untouched, natural environment is filled with opaque causal processes, animal life, and such that are likely to stimulate various cognitive mechanisms, such as the ones that overextend animacy and agency. ${ }^{23}$ The generation of such thought processes leads to relevant ideas that in turn lead to talking, engendering in time the spread of ideas about unseen, powerful agents. In the parlance of cognitive anthropologist Pascal Boyer, counter intuitive concepts will spread through the population (Boyer, 2001). Hence, we have the formation of religious beliefs.

But have we not succumbed to Zuckerman's challenge, then? Is this not saying that religion is somehow "genetically inborn" even "hardwired"? Far from it. The "religious" scenario just provided does not depend on religious concepts being genetically hardwired, independent of environmental factors. The only inborn aspects at play are normal, cognitive mechanisms of the mind-brain which we use to navigate in our mundane, day-to-day environment - such as our ability to detect agency in the environment (in other living organisms and fellow humans), our capacity to infer the intentions of other people ${ }^{24}$ and automatic or intuitive expectations about things in the environment (such as solid objects cannot be in more than one place at a time, that living beings have agency and that people have intentions). ${ }^{25}$ In this account, religiosity (as belief in supernatural agents) is an emergent property arising from the interplay of normal cognitive mechanisms and the immediate natural and social environment (opaque causal processes $\rightarrow$ ideas $\rightarrow$ talking $\rightarrow$ spread of supernatural concepts). Only by removing cognition from its environmental and social niche do we arrive at Zuckerman's caricature of the cognitive science of religion.

Ultimately, the implication of the naturalness hypothesis is one of probability: religiosity is likely but not necessary (and certainly not an existential necessity as the mechanisms involved were not selected by nature for religiosity but for mundane navigation) and, as we will come to in a moment, atheism is less likely but certainly possible, given the right environmental and cultural niche. Again we come to the importance of the interplay between cognition and the natural and cultural environment. In his book Why Would Anyone Believe in God? (Barrett, 2004), Justin Barrett finds the explanation of why people become atheists in the conducive frameworks of western, urbanized societies, which, he argues, are quite the exception in the greater part of human history (Barrett, 2004, pp. 115-118). In such circumstances, it is possible to quiet the unconscious, cognitive mechanisms that underpin religiosity. In urban conditions, the environment is to a large extent man-made, and thus there is much less incentive to interpret causal relations in terms of non-human, supernatural agency. Further, there is a difference in the modern epidemiology of ideas in the sense that naturalistic explanatory frameworks will be more readily available due to higher levels of education. Thus, supernatural explanations face a much steeper competition in modern, urban environments than during our less developed past. Other aspects that Barrett mentions are the plurality in modern societies which, in his opinion, renders the experience of others less relevant to us and, he claims, less urgency of modern living. Thus, it is clear that even advocates of

\footnotetext{
${ }^{22}$ This betrays the utopian aspects of the New Atheist movement which is a matter outside the scope of this article. For a treatment of this aspect of some of the movement's protagonists, see Gray (2008).

23 See Guthrie (1980, 1993), Barrett $(2000,2004)$.

24 This is often referred to as theory of mind (ToM). ToM may be a defining characteristic of human cognition, although this is disputed. Having a theory of mind is characterized by neurologists Gallagher \& Frith as 'our ability to explain and predict other people's behaviour by attributing to them independent mental states, such as beliefs and desires' (Gallagher and Frith, 2003, p. 77). It is a kind of mind reading that underpins our abilities to anticipate, empathize with, and understand other people. It is called a "theory" because it is an assumption about the minds of others.

${ }^{25}$ This is sometimes referred to as "intuitive ontology". For a useful presentation in the context of evolutionary psychology, see Boyer and Barrett (2005)
} 
a strong version of the naturalness hypothesis, such as Barrett, are quite capable of accommodating atheism within their theoretical frameworks. However, in our view, there are several problems with Barrett's portrayal of atheism.

\section{Do atheists need help?}

In his account of atheism, Barrett argues that not believing in God presents people with a number of challenges to the natural cognitive capacities of our minds that must be deliberately overcome. The capacities that are challenged by atheistic belief are a system he calls "hypersensitive agent detection device" (HADD), theory of mind, moral realism, dealing with death and overcoming native creationism. These are claimed to be intuitive cognitive systems or mechanisms which theism has no problems with but which atheism must deal with. Furthermore, atheists must stage their struggle on the basis of articulated, reflective beliefs which are much less direct and automatic than the unreflective beliefs generated by the intuitive cognitive systems (Barrett, 2004, pp. 109-112). Barrett presents several pages on how atheists can combat theism in practice. Strategies include finding salient alternatives to theistic beliefs, limiting HADD outputs by reducing urgency, making sure that HADD sees only human agency, reducing secondhand accounts that might become evidence for God, and surrounding oneself with opportunities for reflective thought (pp. 111-115). These self-help arguments are solely based on an inversion of the logic of the naturalness hypothesis. None of the examples are presented in the context of empirical evidence specific to the supposed challenges that atheists must face.

We argue that one of the many reasons why atheism is becoming widespread is that it draws on the same natural cognitive capacities that theism draws on. We fail to see why HADD, which overreacts to cues in the environment apparently for survival purposes and which must be double-checked for accuracy even by theists, should prove to be a challenge for atheists. Repeated, demonstrated false alarms from HADD should equally reinforce beliefs in non-theistic, natural explanations. ${ }^{26}$ Wouldn't the reasoning mind that concludes, 'No, it's not a tiger that brushed the branch, it's only the wind' also be able to conclude, 'No, it's not my ancestor who pushed the rock from the ledge above, it's only a startled goat'? Does this present a formidable challenge? We argue that the challenge in the latter instance would be to convince the folks back home, especially the professional diviner whose reputation depends on it, that it was indeed only a goat and not an avenging ancestor punishing him for allegedly having illicit sex with a woman in the next village.

As for moral realism, Barrett draws on the fact that the evidence indicates that we have moral capacities whether we are religious or not. He argues, however, that theists have the luxury of moral certitude provided by their religion, whereas atheists must concoct a moral theory to justify it. We argue that atheists also find moral certitude in the ideologies of a just society or in human compassion or simply in enlightened altruism. We argue as well that altruism is also a default mechanism presumably finely honed during our evolutionary history. ${ }^{27}$ This moral realism therefore does not create a challenge to atheists.

Barrett argues that in dealing with death, atheists will have greater difficulty than theists in dealing with the natural sense of disembodied agency by which the grieving stand at the grave communicating with the dead or are filled with anger or guilt due to the passing of a loved one. These scenarios have a speculative ring to them. We don't know how atheists deal with such situations. We do agree with Barrett, however, that guilt for instance is a natural mechanism and can be felt without any apparent reason for it. But this problem must be dealt with by both atheists and theists regardless of their particular persuasions.

Overcoming native creationism is an idea based on studies of children's supposed natural teleology, dualism and creationism. The evidence, however, is contradictory depending on the theory behind the experiments and is still being debated. The evidence can equally be shown to indicate that preschoolers are not natural teleologists, rather that children become more so as they grow older. ${ }^{28}$

\section{Atheism is both ancient and complex}

It is interesting to note, that Barrett's account of atheism is not incompatible with Paul and Zuckerman's point cited above that religion is 'the result of social, political and especially economic conditions' (Paul and Zuckerman, 2007). Anthropologists Saler and Ziegler (2006) draw similar conclusions in their comparison of Barrett's account and sociologist William S. Bainbridge's account of atheism. We will not, however, address Saler's and Ziegler's otherwise provocative and interesting article. ${ }^{29}$

We disagree, however, with the assumption that atheism is more or less the result of the industrial revolution. We agree that the industrial revolution with its subsequent new power structures and new legal norms and institutions has made the mechanisms behind age-old religious assumptions and institutions highly transparent and thus available to critical public assessment. But atheism is not a recent phenomenon, and even though the evidence of the chronological age of atheism is difficult to date, what can be said never the less supports our point.

As with any other human phenomenon, atheism is both old and complex. From its early written expression in Greek philosophy to its apparent connection with Western modernity, it is claimed to be a Western phenomenon (Martin, 2007, p. 3). But this is a misunderstanding, as historian of religions at Aberdeen James Thrower argued in his The Alternative Tradition (Thrower, 1980). Neither claim, Thrower argues, is true. He maintains that irreligion, atheism and materialism are ancient traditions in several parts of the world, and he calls this

\footnotetext{
26 Barrett argues that both HADD and ToM (see note 24) together 'make us prone to find agents, agency, and the consequences of agency in our environment' (Barrett, 2004, p. 109). Our alternative interpretation of the workings of HADD in atheists includes ToM as well.

27 See cognitive scholar of religion Joseph Bulbulia's well-argued studies of altruism in evolutionary perspective (Bulbulia, 2004a, 2004b, 2004c, 2005, 2006). Evidence from primates suggests that the evolutionary roots of morality run deep indeed, see de Waal, 2006 and Werneken and Tomasello, 2009.

28 See the interesting debate on Jesse Bering's experiments on children's beliefs about the immortality of souls with psychologists E. Margaret Evans and Henry M. Wellman, who draw conclusions based on Bering's results that are opposite to Bering's conclusions (Bering, 2006, pp. 490-491; Evans and Wellman, 2006).

29 Saler \& Ziegler wish to extend Barrett's HADD hypothesis. They argue that HADD is a mental module that can be explained in terms of genetics and neurotransmitters. While we agree that neurobiology most certainly plays into such complex phenomena, we suggest that identifying the neural correlates of the hypothesized HADD mechanism would be a necessary precondition for discovering precisely which genes and neurotransmitters that might be involved. Furthermore, there is no evidence that we are aware of which might support the claim that HADD is a module. Almost all claimed psychological constraints, modules, mechanisms and intuitions are amodale (cf. Barsalou, 1999; Barsalou et al., 2003; Schjødt, 2007).
} 
combination of positions "naturalism”. Since Thrower's publication, a recalibration of chronologies has occurred in indological research, but Thrower's basic argument still holds. This persuasion is found here and there in India during the late Vedic period (700-400 B.C.) and in a few of the early Upanishads (7th-5th centuries B.C.), but more specifically in three heterodox movements: Cārvāka school, Jainism and Buddhism (of which the latter two arose around the 5th century B.C.). The date of the Cārvāka school is still uncertain. Indologist Ramkrishna Bhattacharya argues that there is every reason to believe that a senior contemporary of Buddha preached a "protomaterialist" doctrine (Bhattacharya, 2002, p. 601), which would indicate a likely dating of Cārvāka to sometime during the Maurya period (approximately 300-150 B.C.) This approach is also found in the early teachings of the Samkhya school (4th-2nd century B.C.) and the physics and metaphysics of Vaisesika (around the beginning of the common era).

In terms of whether New Atheism really is new, a list of the main tenets of the above-mentioned Cārvāka school is instructive. The Italian historian of religions Giuseppe Tucci summarized it into a number of tenets:

1. Sacred literature should be disregarded as false.

2. There is no deity or supernatural.

3. There is no immortal soul and nothing exists after the death of the body.

4. Karma is inoperative and an illusion.

5. All (that is) is derived from material elements.

6. Material elements have an immanent force.

7. Intelligence is derived from these elements.

8. Religious injunctions and the sacerdotal class are useless. (Thrower, 1980, p. 68; Tucci, 1924).

Tucci suggested that there were two more tenets: 'Only direct perception gives true knowledge' and 'the aim of life is to get the maximum amount of pleasure'. Since Tucci's publication, however, a recent critical investigation of the texts concerning Cārvāka has been published by the above-mentioned Ramkrishna Bhattacharya. It should be noted that our knowledge of the Cārvāka school is unfortunately dependent on quotes from their critics and not on texts from the school itself. Thus a careful critical reading of the texts suggests that although the school did emphasize perception and possibly had a hedonistic aspect, the evidence does not seem to support Tucci's phrasing (Bhattacharya, 2002, pp. 600-602, 618-619).

It is striking, in our opinion, how little difference there is between New Atheists and the Cārvāka school of ancient India. As Thrower concludes, 'This philosophy....is naturalistic (and therefore atheistic in the Western sense of the term) in epistemology, metaphysics and ethics' (Thrower, 1980, p. 68). In fact, it was a materialist philosophy that lasted at least until the 8th or 9th century A.D. (Bhattacharya, 2002, pp. 623-624). Shastri claims that it still exists in obscure but relatively large sects in India today (Shastri, 1925, p. 4f). The reasons for the appearance of such philosophies in India are not as yet completely understood. ${ }^{30}$

One final point we wish to address is that despite his socio-economic arguments, Barrett claims that atheism is a challenge to uphold even for scientists. He claims that there is only a weak correlation between atheism and education within Europe, Canada and the United States based on a survey from 1991 (Barrett, 2004, p. 115). Furthermore, he argues that education alone cannot explain atheism because many reputable scholars in philosophy and science are theists (ibid.). Other surveys, however, show a distinct correlation between atheism and education, despite the fact that well educated people can also be theists. Psychologist of religion Benjamin Beit-Hallahmi has presented a more nuanced discussion of atheism and education in his chapter on the psychological profile of atheists in The Cambridge Companion to Atheism (Beit-Hallahmi, 2007). Studies of students and intellectuals confirm the clear correlation between atheism, intelligence and education. All of the studies on the religiosity of scientists and academics during the 20th century show 'them to be quite irreligious' (Beit-Hallahmi, 2007, p. 307). Furthermore, the more eminent the scientist, the less religious they are as compared to others. Beit-Hallahmi discusses the interesting fact, alluded to by Barrett above, that there is a greater degree of religiosity among physical scientists as compared with social scientists. Beit-Hallahmi suggests that this might be a result of the kind of work that they do. Social scientists are more involved in critical appraisals of social institutions, norms and beliefs whereas physical scientists are more involved in critical thinking about nature and thus at a greater scholarly distance from religion. He suggests that they 'may be able to compartmentalize their science and religion more easily' (p. 309). The important point, we feel, for this discussion is the more overriding fact that these disciplinary differences disappear with growing eminence. In a study conducted on the religiosity of Nobel laureates between 1901 and 2001, Beit-Hallahmi confirmed the "eminence effect" (p. 311). A similar study by Larson and Witham (1997, 1998) on 517 members of the United States National Academy of Sciences indicated that the percentage of believers in a personal God among these scientists was $7 \%$. Belief in personal immortality was 7.9\%. The highest percentage of belief was among mathematicians (14.3\% in God, $15 \%$ in immortality) and the lowest percentage was among biologists (5.5\% in God, 7.1\% in immortality). Physicists and astronomers were slightly higher than biologists.

\section{Adaptationist approaches}

But what about recent, adaptationist approaches in the cognitive science of religion? Do these not imply the necessity of faith? In recent years, the adaptationist approach has provided an alternative paradigm within the evolutionary and cognitive sciences of religion. ${ }^{31}$ This approach also views religion as natural, but instead of maintaining that it is a by-product of adaptations for mundane survival, it claims that religiosity is a functional adaptation in its own right, crafted by natural selection. This may sound like the atheist's ultimate nightmare, and one might be tempted to think that Zuckerman's objections might apply to this camp of naturalists. But even the adaptationist approach

\footnotetext{
30 Thrower has chapters on naturalist philosophies in Greece and Rome, as well as China and short sections on the ancient Near East and Egypt. For a recent introduction to atheism in antiquity see Bremmer, 2007.

31 See Bering, 2002a, 2003, 2004, 2006; Bering et al., 2005; Johnson and Bering, 2006; Sosis, 2000, 2003; Sosis and Alcorta, 2003 ; Sosis and Bressler, 2003; Sosis et al., 2007. For references to Joseph Bulbulia's work, see note 27 as well as Bulbulia et al., 2008.
} 
does not imply the necessity of religion or the unnaturalness of atheism. Let us briefly consider the theory of Jesse Bering, who argues the adaptationist approach.

In brief, Bering theorizes that belief in ambient, unseen agents, such as ancestors, was selected due to its beneficial effects on cooperation in our ancestral past. Bering's theory does not imply that religion is not a by-product of cognitive mechanisms selected for other tasks than religion, but because of beneficiary effects, he claims, religious thought and behavior became entrenched in the human evolutionary landscape:

The psychological foundations of some religious behaviors...may be co-opted spandrels.... They may be side effects of other design features that, quite by chance, had salutary effects of their own on the organism's ability to pass on its genes and, over time, were independently subjected to natural selection (Bering et al., 2005, p. 361, emphasis in original).

Recently, in a brief popular comment on his theory, Bering states that 'God is a way of thinking that has been rendered permanent by natural selection' (Bering, 2007, p. 168, emphasis in original) and that for this reason, religiosity will always be the staple of the masses. Humans can only "silence God" by specially training themselves to do so, and only with partial success: 'As scientists, we must toil and labor and toil again to silence God', but this will not change the fact that there 'will never even be a day when he does not whisper into the ears of the most godless of scientists' (pp. 167-168). The interesting paradox here is that even staunch atheists, such as Bering himself, may continue to "hear" the "voice of God" emanating from the recesses of their mind, no matter their agility with Occam's razor and other thinking aids of the scientific method.

On the face of it, Bering's adaptationist approach may seem to imply the necessity of religiosity. But, as in our review of the naturalness hypothesis above, this is only the case if we remove cognition from its environmental and cultural niche. Cognitivist discourse, which often indicates disdain of the concept of "culture", seems to reflect just that kind of solipsism. To avoid misunderstanding, we are not claiming that cognitivists reject culture as such. We are claiming that they reject culture as a causative factor for human cognition. A few quotes are instructive. To Pascal Boyer, culture 'is the name of a similarity' (i.e. similarity between mental representations in peoples' minds) that has no causal effect: 'How could a similarity cause anything?' (Boyer, 2001, p. 35 and 36). Whatever is happening in human interaction with culture, it is happening 'within their heads' (ibid.), thus Boyer's emphasis on mental tools and inferential constraints. Justin Barrett claims that 'culture cannot explain culture, and religion cannot explain religion' (Barrett, 2004, p. ix). ${ }^{32}$

Such a negligence of the causal effects of culture are, in our opinion, mistaken. Ignoring culture is in many ways a paradoxical and hampering weakness in such cognitive accounts because it ignores a key natural aspect of human cognition, viz. our symbolic and systemic cognitive style. This cognitive style revolves around learning signs and relating them systematically to one another. Thus, to echo neuroscientist and biosemiotician Terrence Deacon and his theory of humans as a symbolic species, we are perpetual systemizers: all things in our natural and cultural environment can, potentially, be put into symbolic-systemic relations to any other thing (Deacon, 1997, pp. 92ff, pp. 433ff). ${ }^{33}$ This systemic quality not only enables us to use language, it further enables us to learn, navigate and maintain systems of ideas, making us the purveyors and peddlers of ideologies, morals, norms, philosophies, science, fiction, sense and nonsense. Thus, when Bering's automatic cognitive mechanisms are considered in the wider context of this striking natural quality of human cognition, religiosity no longer becomes a necessity. Immersed in such rich and structured niches, armed with their species-specific ability for abstract thought, humans can learn to draw other conclusions from the output of Bering's religious-cognitive systems than religious ones and thus acquire the cognitive habit of atheism (in our view, this is quite in keeping with Bering's notion of "silencing God").

With these biocultural aspects in mind, they may reveal that the voices emanating from within our heads are anything but heavenly.

\section{Howling discontent}

While we are persuaded that Bering has identified important aspects of human cognition, we are somewhat skeptical of his turns of phrase. For instance, he writes that until we rear our children to ignore the voice of God, 'he will continue to howl his discontent for all of time' (Bering, 2007, p. 168). He uses more neutral terminology in his scientific articles, but his phrasing is sometimes echoed even there. Much of his phrasing is speculative and assumes an existential agony that supposedly accommodates atheism, a notion we encountered previously with Barrett. ${ }^{34}$ We argue here that this apparent agony, if credible, may equally be a result of discovering the futility of their prior religious beliefs and not of the realization that God is a human construction. Bering, we believe, is closer on the mark with his question in an article on Sartre, 'Why is the individual's subjective worldview so completely saturated with private symbolic meaning?' (Bering, 2008, p. 363). Bering goes on to claim, however, 'that is to say, we must focus on the individual's relationship with God'. We disagree. Both Deacon with his biosemiotic theory and psychologist Merlin Donald with his biocultural evolutionary account can answer Bering's question without recourse to God (Geertz, 2008b). Humans are 'a “symbolic species” in a deeply physiological sense', Deacon claims (Deacon, 2003a, p. 95). Humans, Merlin Donald argues, are 'culture-mongers seeking solace in community' (Donald, 2001, p. 253). We cannot even use our large brains without cultural frameworks. If God happens to be a part of that framework, then that's the way things are. If not, then that's the way things are too.

In light of such biocultural accounts, the voice of God that Bering cannot suppress could be the voice of the "generalized other", to use George Herbert Mead's phrasing. For Mead, the internal conversation is carried on by the individual from the standpoint of the generalized

\footnotetext{
32 We will return to this issue below in the section "Of minds and memes".

33 Deacon's thesis has much in common with Merlin Donald's treatise A Mind So Rare (2001).

34 Bering refers to atheism in a number of publications (see for instance Bering, 2006), and devotes a section on atheism in his 2002 article on the existential theory of mind (Bering, 2002a, pp. 18-19). Atheism also figures in three empirical studies (Bering, 2002b; Bering and Bjorklund, 2004; Bering et al., 2005). Despite being persuaded that Bering has identified important aspects of human cognition, we feel it may be somewhat hasty to draw general and universal conclusions based on these experiments. The experiments need to be replicated in a number of other Western as well as non-Western countries as well as on a variety of participants from different walks of life. Would it make a difference, for instance, to test men and women in societies with significantly higher percentages of irreligiosity than in the United States? Would the results vary according to social and gender distinctions? As Beit-Hallahmi noted, 'Being an atheist overwhelmingly means being male. Data from all cultures show women to be more religious than men' (Beit-Hallahmi, 2007, p. 301). Furthermore, what would the results be like in countries that are either officially atheistic or officially religious?
} 
other (Mead, 1934, p. 155, n.8). The self, as an object to itself, is the social structure that an individual is immersed in. The very essence of our social intelligence is the ability to take on the attitudes and roles of others, 'thus realizing', Mead argues, 'the significations or grasping the meanings of the symbols or gestures in terms of which thinking proceeds; and thus being able to carry on with himself the internal conversation with these symbols or gestures which thinking involves' (p. 141, n.3). 'Only through the taking by individuals of the attitude or attitudes of the generalized other toward themselves', Mead argues, 'is the existence of a universe of discourse, as that system of common or social meanings which thinking presupposes a[s] its context, rendered possible' (p. 156).

Thus, the inner voice we hear may be our own voice articulating intimate messages from the social voices around us. We are helpless in discriminating between our minds and other minds because "mind" is not a solipsistic device. It is a collective device not only finely tuned to pick up the cultural and social cues necessary for personal well-being and identity but also to establish its very existence from those cultural and social cues. ${ }^{35}$

\section{of minds and memes}

Above, we considered the differences between the naturalness and unnaturalness hypothesis. In this final section, we will consider their combination.

The background of the unnaturalness hypothesis is meme theory (Blackmore, 1999; Dawkins, 1976; Dennett, 1995), where memes are viral parasites or symbionts that take advantage of human brains and the cultural environment. Among the figures that have had formative influence on the naturalness hypothesis with its cognitive emphasis (not the least on Boyer, cf. Jensen, 2009) is French anthropologist Dan Sperber $(1985,1996)$ with his concept of the "epidemiology of representations" (i.e. that certain concepts that "excite" the natural, cognitive mechanisms of the mind-brain have a greater chance to spread through a population than other concepts, viz. that they are more "catchy"). The spread of cultural forms (memes/representations) within a population is central to both memetics and such cognitive, epidemiological accounts of culture.

Subtle differences, however, between meme theorists and cognitive scientists of religion and culture lie in where they posit "ontology" or "efficacy". Dawkins and proponents of memetics posit efficacy and ontology in cultural information (memes) that take advantage of host brains. Cognitivists, on the other hand, posit efficacy and ontology in the human mind-only the mind is causally effective, not cultural information (Boyer, 2001, p. 35f; Pyysiäinen, 2002, p. 177, 2003, p. 25ff; Sperber, 2000). Consequently, memeticists are culturalists, since they maintain that memes have efficacy of their own, while cognitivists claim that culture is an epiphenomenon. The difference is also apparent in memeticists' emphasis on copying, where memes are copied from one brain to another, and in cognitivists' emphasis on inference, where the individual mind arrives at similar conclusions as its fellow minds, thus generating culture from within. This latter notion is sometimes termed "evoked culture."36

We argue that both camps are making important points. The strength of the cognitive approach, as we have argued above, lies in its power to carve cultural phenomena at its "universal joints". Its weakness, however, becomes apparent when we note how far culture can stray from its cognitive "bedrock". ${ }^{37}$ The biggest problem with meme theory, however, is that memes are defined by replacing one meaningless term for another: Dawkins, Dennett and Blackmore often designate memes as information but, ultimately, say little about what information is (cf. Deacon, 1999). We maintain that the natural (cognitive) and unnatural (memetic) hypotheses are not mutually exclusive and should be combined for a fuller account of cultural phenomena. ${ }^{38}$ But for that to happen, the joys of science fiction notwithstanding, memes must be rescued from the brave new worlds of Blackmore and Dennett.

Terrence Deacon has argued that making "information" an intrinsic quality of the meme is untenable. This becomes apparent when one applies a semiotic framework. Memes, like genes, Deacon argues, cannot be understood "without considering their embeddedness in a dynamic system which imbues them with their function and informational content' (Deacon, 1999, p. 2). Genes are just physical patterns, in the same sense that letters on a page are just patterns. Patterns, in and of themselves, are meaningless. Genes, letters, or any signs for that matter, first become significant as "carriers" of information when they are interpreted by an active subject-in the case of genes, the cell, in the case of printed pages, a cognizing human. What counts as information, Deacon claims, is always context-dependent and thus cannot be an intrinsic quality. For Deacon, memes are simply signs (physical patterns), and their information content is embedded in semiotic systems. In consequence, Deacon argues, 'genes and memes are not the locus of the replication process, nor are they somehow the functional unit of information. They are replicas not replicators. They are rather more like the concretion of information bottlenecks in a system' (p. 2). We see in Deacon's approach the beginnings of a demystification of the meme concept. Further steps in this direction could provide the basis for understanding cultural evolution removed from the attractors of intuitive, cognitive mechanisms.

\section{Coming full circle: making the unnatural natural}

The important points of the unnaturalness hypothesis lie in its emphasis on the context of learning and social status and the evolution of cultural forms removed from the pull of intuitive, cognitive mechanisms. Thus, where the naturalness hypothesis with its emphasis on universal, cognitive aspects leaves off, the unnaturalness hypothesis steps in. Our intuitive, hyperactive agency detection device (HADD) may induce us to infer the presence of supernatural agents but the particular powers, forms, and tendencies that these agents may possess, and whether they deserve ritual attention, are doctrinal issues dictated by authority figures (such as parents and elders), often to the young

\footnotetext{
35 This conclusion is reminiscent of Michael Tomasello's thesis in The Cultural Origins of Human Culture, e.g. his emphasis on intersubjectivity and the ability to take the perspectives of others (Tomasello, 1999).

36 See Cosmides and Tooby, 1992, p. 206ff; Tooby and Cosmides, 1992, p. 114ff.

37 An obvious example is modern science, an example of what Merlin Donald calls "theoretic culture", which depends on highly developed, external memory stores (Donald, 2001).

38 Our position is similar to that of evolutionary anthropologists Peter J. Richerson and Robert Boyd who acknowledge both the cognitivist notion of evoked culture and the more memetic notion of transmitted culture (Richerson and Boyd, 2005).
} 
and impressionable. HADD may make concepts of supernatural agents both relevant and plausible (cf. Barrett, 2004; Boyer, 2001), but the plausibility and relevance of details of doctrine-such as the trinity, the incarnation, final judgment and so on-depends on receiving such ideas from revered, authoritative sources. In this vein, cognitive anthropologist Harvey Whitehouse has pointed out that

$[R]$ ligious traditions are much more than just the sum of various universal themes. Some religions involve highly elaborated and distinctive cosmologies.... Others incorporate extensive ethical systems that run against the grain of intuitive moral reasoning.... [A]ll these gloriously diverse ideas are often linked together in ways that might be described as systemic. So we talk quite reasonably about religious systems.... (Whitehouse, 2008, p. 36f, emphasis in original).

Various significant cultural processes vanish if we restrict our optics to universal cognitive mechanisms. Take, as a general example, the stability of such religious systems, as mentioned by Whitehouse, and the fact that they can be transmitted across generations. Markússon has recently argued that a striking membership increase in a certain marginal non-Christian denomination in Iceland (as opposed to other marginal denominations) cannot be explained in terms of cognitive mechanisms but must depend on cultural dynamics, such as the local ecology of signs (Markússon, in press). If such processes are not to vanish from our spectrum, we need cognitive and cultural approaches to complement each other.

However, as we have suggested above, taking the unnaturalness hypothesis or memetics of Dawkins and his circle seriously is only to acknowledge a general principle - that cultural forms can evolve away from cognitively optimal positions. To go beyond that, in our opinion, we need to enter various theoretical realms, among them complexity theory, biosemiotics and biocultural theories. ${ }^{39}$ In a nutshell, these approaches imply hierarchical levels of causation (say, cognitive and cultural) and situate cognition in a web of ecological and cultural scaffolding.

Within the ranks of the cognitive science of religion, we find the beginnings of such an approach in Whitehouse's theory of the imagistic and doctrinal modes of religiosity (Whitehouse, 2004). ${ }^{40}$ The imagistic mode pertains to rituals and religious knowledge that are performed and transmitted with low frequency (with long intervals of time), such religiosity being characterized by extreme stimulations that impact memory and exegesis for long periods (such as initiation rites). Thus, with its impact on memory, the imagistic mode serves as scaffolding for complex religious ideas and ritual knowledge independent of normal cognition. ${ }^{41}$ The doctrinal mode, on the other hand, secures the transmission of rituals and doctrine by high frequency performance and transmission (with short intervals of time), such religiosity being much less extreme, but more prone to tedium, and subject to orthodoxy and religious authorities (such as the Roman Catholic Mass). By the effects on memory of frequent rehearsal, the doctrinal mode provides another kind of scaffolding for complex religious and ritual knowledge independent of normal cognition. Whitehouse accounts for the historical development of religion in terms of the imagistic and doctrinal modes emerging in the wake of normal cognition (Whitehouse, 2000, chap. 8; 2004, p. 77ff.; 2008). In his scenario, the most ancient forms of religiosity - some possibly as old as humanity itself - are those pertaining to the naturalness hypothesis (such as belief in supernatural agents). This is because the postulated cognitive mechanisms of the naturalness hypothesis are the results of biological evolution and thus the portents of our species. He argues that the imagistic mode was the second stage in the history of religion, emerging at least as early as the Upper Paleolithic. By some external ecological pressure, groups started performing extreme rituals, such as initiations, that enhanced cohesion and thus cooperation and survival. Finally, the emergence of the doctrinal mode, Whitehouse maintains, coincided with the development of agriculture which, with its regulatory cycles of labor and the development of complex social organization, fostered the routinization of ritual and religion and the emergence of religious authorities. Thus, to sum up Whitehouse's account, 1) normal cognition (the naturalness hypothesis), 2) the imagistic and 3) doctrinal modes account for the historical evolution of religious systems. While we agree that Whitehouse has identified plausible candidates for potentially ancient external scaffolding for the transmission of religious ideas removed from natural, cognitive positions, we argue that we need to take into account a variety of other aspects of cultural scaffolding if we are to achieve a comprehensive account of the evolution of religious ideas and cultural forms.

One of the relevant issues is Deacon's biosemiotic notion of symbolic and systemic cognition, mentioned above. Deacon's approach entails that human symbolic cognition, enabled by the expansion of the prefrontal cortex, is situated in an ecology of signs (symbols, indices and icons) which serve as scaffolding for the evolution of cultural forms (Deacon, 1997, 1999). The semiotic component of Deacon's theory puts emphasis on the importance of external mnemonics, such as artefacts, diagrams and writing, for the transmission and maintenance of culture, elements that play a minor role in Whitehouse's account. Maintaining intricate religious systems and transmitting their relevant aspects will, we maintain, often go beyond frequent repetition of doctrine and, in addition, involve the navigation of a semiotic niche by way of the human capacity of symbolic, systemic cognition.

Another relevant issue is distributed cognition. Whitehouse states that the transmission and maintenance of doctrine, removed from natural cognition, depends on storage in semantic memory. He then goes on to say that 'semantic memory, however, can only store large bodies of information through processes of regular rehearsal' (Whitehouse, 2008, p. 38). While we don't dispute the importance of semantic memory in this context, we note that Whitehouse's discussion seems to imply that such traditions depend on individuals committing the whole tradition of knowledge-or large chunks of it at any rate-to memory. This strikes us as implausible. A much more parsimonious strategy for the maintenance and transmission of such conceptual information would be distributed cognition. Donald, in his scenario of language origins, argues that a simulacrum of language need not be built into every single brain rather, to the contrary, brains need only to fit into a communicative environment 'as parts of a distributed web' (Donald, 2001, p. 284). Donald goes on to say that our 'cultural storehouses far exceed what any brain could possibly copy or remember, and no single brain can totally comprehend every aspect of a symbolic cultural

\footnotetext{
39 A few suggestive references are: On complexity theory see e.g. Kauffman, 2008; Lewin, 1999; Solé and Goodwin, 2000. On biosemiotics, see e.g. Barbieri, 2008; Deacon, 1997, 1999, 2003a, 2003b; Hoffmeyer, 1996, 2005. On biocultural theories, see e.g. Clark, 1997; Donald, 2001; Tomasello, 1999. On complexity theory in the context of the cognitive science of religion, see Malley, 1995, 1997; see also a discussion in Pyysiäinen (2003, p. 31ff).

40 Cognitive scientist of religion Matthew Day makes this point in a recent article. Our account of situated cognition and scaffolding has much in common with his (Day, 2005).

${ }^{41}$ By "independent of normal cognition" is meant ideas and knowledge that are not explained by the naturalness hypothesis.
} 
environment, let alone generate one' (p. 285). ${ }^{42}$ Applying this to a religious (or any) system of ideas would imply distributing conceptual information amongst different individuals or groups, so that each one would only commit parts of the system to memory. Furthermore, external mnemonics (signs, texts, diagrams, illustrations, artifacts, and so on) would enable the offloading of concepts into the environment (piggybacking, in Donald's parlance). Such offloading is not at all mysterious or metaphysical, as is sometimes implied by cognitivists. External mnemonics are part of our material and perceptive environment, 'offloaded concepts' being approximately recreated when individuals or groups interact with them. Such interaction with external mnemonics would be an example of what Deacon terms 'interpretive responses' (Deacon, 1997, p. 63), referring to the Peircian semiotic concept semiosis. ${ }^{43}$ External mnemonics, especially texts, further entail that they can be carried "silently" through generations without being interacted with, much like so-called junk DNA in biological lineages. Historical contingencies can then lead to their sudden reapplication and reinterpretation, thus leading to novel concepts (or approximate recreations of forgotten ones) in response to unexpected circumstances. Just as distributed cognition is a parsimonious strategy to store and transmit conceptual knowledge, so would the possibility to reapply 'junk text' in novel situations increase the adaptability of religious and ideological systems.

To return to our theme of atheism, we argue that within a framework such as this-which accommodates cognition and culture, admitting both the cognitive mechanisms championed by "cognitivists" and the biosemiotic or biocultural approaches of "culturalists"-atheism emerges as a reasonable interpretative response and a natural strategy. Thus, having made the unnatural natural, we have come round full circle.

\section{Understanding the new atheism}

We close this article by returning to the New Atheism movement, considering its propagation from our cognitive-cultural perspective. ${ }^{44}$ As this is a recent movement, one must bear in mind that any analysis at this stage is preliminary. Be that as it may, a few suggestions can be made.

The most obvious statement about the New Atheism is that it was ignited by the shattering events of September 11, 2001. One might even say that "the post 9/11 atheist movement" is more accurate than "New Atheism". ${ }^{45}$ Richard Dawkins responded to the attacks already on September 15th in the Guardian in a piece entitled "Religion's misguided missiles" (Dawkins, 2001). In The End of Faith, Sam Harris wrote 'I began writing this book on September 12, 2001. Many friends read and commented on a long essay that I produced in those first weeks of collective grief and stupefaction, and that text became the basis for this book' (Harris, 2004, p. 333). However, pointing to 9/11 does not get us very far. For one thing, it is an oversimplification. While 9/11 may have driven Dawkins to write The God Delusion, the book is also the culmination of his long-standing opposition to religion and religion's place in society, a career of critique antedating 9/11 by decades. Furthermore, 9/11 tells us very little about the continued strength and propagation of New Atheism.

In light of biosemiotics, operating with an analogy between biological and cultural systems, ${ }^{46}$ New Atheism can be said to be characterized by:

1) a rich and continually expanding ecology of signs (or external mnemonics) provided by books, websites, TV programmes, and so forth.

2) a culture of reactionary interpretative responses to those signs (a reactionary semiosis) and

3) well known, authoritative spokespersons, providing semiotic authority.

All three elements serve to spread and maintain New Atheism.

1) A rich ecology of signs increases adaptability as it makes it possible to employ different "segments" of signs (texts, and so on) in response to different circumstances (an analogy to cells applying different segments of DNA in different contexts). Externalization techniques like signs/mnemonics further enable the "offloading" of complex concepts into the environment, thus securing their spread and transmission. Within a relatively brief number of years, variously linked concepts such as memes, genes, rationality, secularism, science, naturalism, democracy, religion-as-a-delusion, religion-as-a-virus-of-the-mind, religion-as-abuse and so on became determining hallmarks of New Atheist semiotic ecology.

2) A reactionary semiosis, exemplified by New Atheists' activities on the web, in the media, in publications, and so on, further enables quick adaptation to varying circumstances. In order to secure the transmission of atheist thought, New Atheists have been engaged in systematic and aggressive criticism and deconstruction of theist claims. Books, blogs, debates, TV-interviews, conferences and judicial suits are vigorously used. But also more constructive and more socially encouraging measures are employed to help socialize the children of atheists, to persuade intellectuals at universities and to counsel new converts.

An interesting avenue of future research, we think, could be to study the effects of reactionary semiosis, if any, on intuitive psychology. With reference to our discussion of Barrett and Bering above, it would be interesting to identify any possible effects of the sense of

\footnotetext{
42 Donald's discussion is in the context of a critique of Chomsky's concept of an innate Universal Grammar. We do not mean to imply that Whitehouse is unaware of distributed cognition, but his mentioning of it is very much in passing (cf. Whitehouse, 2008). Further, external mnemonics other than the imagistic and doctrinal modes play hardly any role in his theory (cf. Whitehouse, 2008, 2004).

43 Semiosis refers to the dynamics involving 1 ) a physical sign, 2) a cognizing subject that interprets the sign, and 3) the result of its interpretation, viz. the sign's meaning. The physical sign (1), strictly speaking, is only a physical pattern. The sign proper involves all three components (cf. Hoffmeyer, 1996, p. 19; Peirce, 1955a, p. 99, 1955b, p. 282). Thus, the sign is really a relationship that emerges in the interaction of external mnemonics and cognizing subjects. In the real world, semiosis continually takes place in a distributed web of cognizing subjects navigating their ecological niche of physical signs (or external mnemonics).

${ }^{44}$ While some may object to calling the New Atheism a "movement", it cannot be denied that there is significant coordination among its proponents, e.g. through highprofile websites, and applying the term movement is much more practical than, say, "a series of coordinated and half-coordinated initiatives".

45 The latter term, however, is the one that has emerged in the media, e.g. the cover of WIRED magazine, November 2006, and we apply it here for that practical reason.

${ }^{46}$ DNA:cell::signs:cognizing subjects. DNA is interpreted by the cell as cultural signs (external mnemonics, texts, diagrams, artifacts, etc) are interpreted by cognizing humans.
} 
urgency that often seems entailed by reactionary semiosis. Barrett considers urgency as important in triggering psychological mechanisms that underpin religious beliefs. Could it be that urgency triggers the same mechanisms in New Atheists? Could such triggering give New Atheist concepts an intuitive sense, similar to that of religious concepts, as Barrett claims? Another interesting question would be how the output of such mechanisms is dealt with, in other words, how they are rerouted to naturalistic conclusions. We are aware that this is pure speculation, but we could begin to test this hypothesis by looking at whether there is a link between reactionary semiosis, urgency and the activation of certain psychological mechanisms (if such mechanisms could be delimited).

3) Arguments from authority ${ }^{47}$ give credit to certain trends of semiosis rather than others. Certainly the main authorities are Dawkins, Dennett, Harris and Hitchens, but other established authorities are also present in atheist and humanist organizations, such as Michael Shermer (Skeptics Society), Paul Kurtz (Council for Secular Humanism), not to mention renowned authors like Salman Rushdie and Ian McEwan. Much care is taken to establish and cite older-even ancient-authorities, such as Albert Einstein, Bertrand Russel, Charles Darwin, David Hume, Thomas Hobbes and Lucretius. A good example of this is the atheist reader edited by Hitchens, The Portable Atheist: Essential Readings for the Nonbeliever (Hitchens, 2007b). And even cognitive scientists of religion, such as Pascal Boyer and Dan Sperber, have become authority figures for some New Atheists.

In this perspective, the New Atheist movement is a complex system of signs/external mnemonics and distributed cognition, well adapted to the uneasy world of popular media and social activism. These formal, semiotic aspects, we suggest, are key factors in the movement's spread and maintenance. To restrict New Atheism to the individual brains of New Atheists is insufficient grounds for any claims on the cognitive naturalness or unnaturalness of atheism. Modern, Western cultural, political and social contexts function as the supportive framework for atheist cognition-just as they do for religious cognition.

\section{Conclusion}

In the course of this paper, after considering irreligion and the New Atheism, we have refuted Zuckerman's claim that statistics on atheism pose a problem for cognitive accounts of religion. Neither the by-product nor the adaptationist hypotheses of the naturalness approach make religiosity a necessity for humans. Such would only be the case if we were to remove cognition from its socio-cultural habitat. However, cognitive accounts often proceed as if the wider cultural ecology can be ignored. To amend this, the naturalness and unnaturalness (or memetic) hypotheses must be combined, bringing cognition and culture back together again. In redirecting attention to the fact that human cognition is always situated within a natural habitat of cultural systems, we find that atheism is no less natural than religiosity is. We are therefore critical of the cognitive science of religion accounts of atheism and their unsupported assumptions about atheists.

In the end, religiosity and atheism represent entrenched cognitive-cultural habits where the conclusions drawn from sensory input and the output of cognitive systems bifurcate in supernatural and naturalistic directions. The habit of atheism may need more scaffolding to be acquired, and its religious counterpart may need more effort to kick, but even so, that does not, ipso facto, make the latter more natural than the former.

\section{References}

Adler, J., 2006. The new naysayers. Newsweek. http://www.newsweek.com/id/45574 updated October 15, 2007.

Aikman, D., 2008. The Delusion of Disbelief: why the New Atheism is a threat to your life, liberty, and pursuit of happiness. Tyndale House Publishers, Carol Stream. Aronson, R., 2007. The new atheists. The Nation June 7. http://www.thenation.com/doc/20070625/aronson.

Barbieri, M. (Ed.), 2008. Introduction to Biosemiotics: the new biological synthesis. Springer, Dordrecht.

Barrett, J., 2000. Exploring the natural foundations of religion. Trends in Cognitive Science 4, 29-34.

Barrett, J., 2004. Why Would Anyone Believe in God? Altamira, Walnut Creek.

Barrett, J., 2007. Is the spell really broken? Bio-psychological explanations of religion and theistic belief. Theology and Science 5 (1), 57-72.

Barry, B.A., Mayer, E.M., Keysar, A., 2001. American Religious Identification Survey 2001. The Graduate Center of the City University of New York, New York.

Barsalou, L.W., 1999. Perceptual symbol systems. Behavioral and Brain Sciences 22, 577-660.

Barsalou, L.W., Simmons, W.K., Barbey, A.K., Wilson, C.D., 2003. Grounding conceptual knowledge in modality-specific systems. Trends in Cognitive Sciences 7 (2), 84-91. Beit-Hallahmi, B., 2007. Atheists: a psychological profile. In: Martin, M. (Ed.), The Cambridge Companion to Atheism. Cambridge University Press, Cambridge, pp. 300-317. Bering, J.M., 2002a. The existential theory of mind. Review of General Psychology 6 (1), 3-24.

Bering, J.M., 2002b. Intuitive conceptions of dead agents' minds: the natural foundations of afterlife beliefs as phenomenological boundary. Journal of Cognition and Culture 2 (4), 263-308.

Bering, J.M., 2003. Towards a cognitive theory of existential meaning. New Ideas in Psychology 21, 101-120.

Bering, J.M., 2004. A critical review of the "enculturation hypothesis": the effects of human rearing on great ape social cognition. Animal Cognition 7, $201-212$.

Bering, J.M., 2006. The folk psychology of souls. Behavioral and Brain Sciences 29, 453-498.

Bering, J.M., 2007. Science will never silence god. In: Brockman, J. (Ed.), What Is Your Dangerous Idea? Today's leading thinkers on the unthinkable. Pocket Books, London, Sidney, New York, Toronto, pp. 167-168.

Bering, J.M., 2008. How Sartre inadvertently presaged a proper evolutionary science of religion. In: Bulbulia, J., et al. (Eds.), The Evolution of Religion: studies, theories, \& critiques. Collins Foundation Press, Santa Margarita, pp. 357-364.

Bering, J.M., Bjorklund, D.F., 2004. The natural emergence of reasoning about the afterlife as a developmental regularity. Developmental Psychology 40 (2), $217-233$.

Bering, J.M., McLeod, K., Shackelford, T.K., 2005. Reasoning about dead agents reveals possible adaptive trends. Human Nature 16 (4), $360-381$.

Berkowitz, P., 2007. The new atheism. The Wall Street Journal July 16, 2007. http://www.opinionjournal.com/forms/printThis.html?id=110010341.

Bhattacharya, R., 2002. Cārvāka fragments: a new collection. Journal of Indian Philosophy 30, 597-640.

Blackmore, S., 1999. The Meme Machine. Oxford University Press, Oxford.

Boyer, P., 1994. The Naturalness of Religious Ideas: a cognitive theory of religion. University of California Press, Berkeley.

Boyer, P., 2001. Religion Explained: the evolutionary origins of religious thought. Basic Books, New York.

Boyer, P., Barrett, C., 2005. Domain specificity and intuitive ontology. In: Buss, D. (Ed.), The Handbook of Evolutionary Psychology. John Wiley \& Sons, New Jersey, pp. 96-118. Bremmer, J.N., 2007. Atheism in antiquity. In: Martin, M. (Ed.), The Cambridge Companion to Atheism. Cambridge University Press, Cambridge, pp. 11-26.

Bulbulia, J., 2004a. The cognitive and evolutionary psychology of religion. Biology and Philosophy 19, 655-686.

\footnotetext{
47 This last point is not meant to make any claims for or against the rationality of the views of New Atheists. It is simply an observation to the effect that New Atheists are human and, like the rest of us, willy-nilly prone to arguments from authority.
} 
Bulbulia, J., 2004b. Religious costs as adaptations that signal altruistic intention. Evolution and Cognition 10 (1), 19-42.

Bulbulia, J., 2004c. Evolutionary game theory and supernatural causation. In: Bulbulia, J., Morris, P. (Eds.), What Is Religion for? New Zealand Association for the Study of Religions \& Victoria University of Wellington, Wellington, pp. 13-31.

Bulbulia, J., 2005. Are there any religions? An evolutionary exploration. Method \& Theory in the Study of Religion 17 (2), 71-100.

Bulbulia, J., 2006. Nature's medicine: religiosity as an adaptation for health and cooperation. In: McNamara, P. (Ed.), Where God and Science Meet: how brain and evolutionary studies alter our understanding of religion. Vol. 1. Evolution, Genes, and the Religious Brain. Praeger Publishers, Westport \& London, pp. 87-121.

Bulbulia, J., Sosis, R., Harris, E., Genet, R., Genet, C., Wyman, K. (Eds.), 2008. The Evolution of Religion: studies, theories, \& critiques. Collins Foundation Press, Santa Margarita. Clark, A., 1997. Being There: putting brain, body and world together again. MIT Press, Cambridge.

Cosmides, L., Tooby, J., 1992. Cognitive adaptations for social exchange. In: Barkow, J.H., et al. (Eds.), The Adapted Mind: evolutionary psychology and the generation of culture. Oxford University Press, New York, pp. 163-228.

Dawkins, R., 1976. The Selfish Gene. Oxford University Press, Oxford. reprint, 1999.

Dawkins, R., 1993. Viruses of his mind. In: Dahlbom, B. (Ed.), Dennett and His Critics: demystifying mind. Blackwell, Cambridge, pp. $13-27$.

Dawkins, R., 2001. Religion's misguided missiles: promise a young man that death is not the end and he will willingly cause disaster. Guardian September 15th. www. guardian.co.uk/Archive/Article/0,4273,4257777,00.html.

Dawkins, R., 2006. The God Delusion. Bantam Press, London.

Dawkins, R., 2007. Richard Dawkins replies to David Sloan Wilson. ESkeptic. The Email Newsletter of the Skeptic Society July 11 html. http://www.skeptic.com/eskeptic/0707-11.html.

Day, M., 2005. Rethinking naturalness: modes of religiosity and religion in the round. In: Whitehouse, H., McCauley, R.N. (Eds.), Mind and Religion: psychological and cognitive foundations of religiosity. Alta Mira Press, Walnut Creek, pp. 85-106.

Deacon, T.W., 1997. The Symbolic Species: the co-evolution of language and the human brain. Allen Lane The Penguin Press, London.

Deacon, T.W., 1999. Memes as signs: the trouble with memes (and what to do about it). The Semiotic Review of Books 10 (3), 1-3.

Deacon, T.W., 2003a. Multilevel selection in a complex adaptive system: the problem of language origins. In: Weber, B.H., Depew, D.J. (Eds.), Evolution and Learning: the Baldwin effect reconsidered. MIT Press, Cambridge, pp. 81-106.

Deacon, T.W., 2003b. The hierarchic logic of emergence: untangling the interdependence of evolution and self-organisation. In: Weber, B.H., Depew, D.J. (Eds.), Evolution and Learning: the Baldwin effect reconsidered. MIT Press, Cambridge, pp. 273-308.

Dennett, D.C., 1995. Darwin's Dangerous Idea: evolution and the meanings of life. Penguin Books, London.

Dennett, D.C., 2006. Breaking the Spell: religion as a natural phenomenon. Penguin Group, New York.

Dennett, D.C., Swinburne, R., 2006. How should we study religion? Prospect Magazine 120. http://www.prospect-magazine.co.uk/article_details.php?id=7365.

Donald, M., 2001. A Mind so Rare: the evolution of human consciousness. Norton, New York, London.

Eller, D., 2004. Natural Atheism. American Atheist Press, Cranford.

Eller, D., 2007. Atheism Advanced: further thoughts of a freethinker. American Atheist Press, Cranford.

Evans, E.M., Wellman, H.M., 2006. A case of stunted development? Existential reasoning is contingent on a developing theory of mind. Behavioral and Brain Sciences 29 (5), $471-472$.

Gallagher, H.L., Frith, C.D., 2003. Functional imaging of 'theory of mind'. Trends in Cognitive Sciences 7 (2), 77-83.

Geertz, A.W., 2008a. How not to do the cognitive science of religion today. Method \& Theory in the Study of Religion 20 (1), 7-21.

Geertz, A.W. 2008b. Religion and cognition: a crisis in the academic study of religion? CSSR Bulletin 37 (4), 91-95.

Geertz, A.W., 2009a. New atheistic approaches in the cognitive science of religion: on Daniel Dennett, Breaking the spell (2006) and Richard Dawkins, The God delusion

(2006). In: Stausberg, M. (Ed.), Contemporary Theories of Religion: a critical companion. Routledge, New York, pp. 242-263.

Geertz, A.W., 2009b. When cognitive scientists become religious, science is in trouble: on neurotheology from a philosophy of science perspective. Religion.

Gottlieb, A., 2007. Atheists with attitude. The New Yorker May 21. http://www.newyorker.com.

Gray, J., 2008. Black Mass: apocalyptic religion and the death of Utopia. Penguin Books, London.

Guthrie, S.E., 1980. A cognitive theory of religion. Current Anthropology 21 (2), 181-203.

Guthrie, S.E., 1993. Faces in the Clouds: a new theory of religion. Oxford University Press, New York \& Oxford.

Hahn, S., Wiker, B., 2008. Answering the New Atheism: dismantling Dawkins' case against god. Emmaus Road Pub., Steubenville.

Haidt, J., 2007. Moral psychology and the misunderstanding of religion. Edge. The Third Culture. http://www.edge.org/3rd_culture/haidt07/haidt07_index.html.

Harris, S., 2004. The End of Faith: religion, terror, and the future of reason. W.W. Norton \& Co., New York.

Harris, S., 2006. Letter to a Christian Nation. Knopf, New York.

Haught, J.F., 2008. God and the New Atheism: a critical response to Dawkins, Harris, and Hitchens. Westminster John Knox Press, Louisville.

Hitchens, C., 2007a. God Is Not Great: how religion poisons everything. Twelve Books, New York.

Hitchens, C. (Ed.), 2007b. The Portable Atheist: essential readings for the nonbeliever. Da Capo Press, Philadelphia.

Hoffmeyer, J., 1996. Signs of Meaning in the Universe. Indiana University Press, Bloomington.

Hoffmeyer, J., 2005. Biosemiotik. En afhandling om livets tegn og tegnenes liv. Ries, Copenhagen, Biosemiotics: An examination into the signs of life and the life of signs. Translated by Jesper Hoffmeyer and Donald Favareau. University of Scranton Press, Scranton, 2008.

Jensen, J.S., 2009. Religion as the unintended product of brain functions in the 'standard cognitive science of religion model': on Pascal Boyer, Religion explained (2001) and

Ilkka Pyysiäinen, How religion works (2003). In: Stausberg. M. (Ed.) Contemporary Theories of Religion: a critical companion. Routledge, New York, pp. 129-155.

Johnson, D., Bering, J.M., 2006. Hand of god, mind of man: punishment and cognition in the evolution of cooperation. Evolutionary Psychology 4, 219-233.

Kauffman, S.A., 2008. Reinventing the Sacred: a new view of science, reason, and religion. Basic Books, New York.

Koch, G., 2008. Full of sound and fury: the media response to Dennett. Method and Theory in the Study of Religion 20 (1), 36-44.

Larson, E.J., Witham, L., 1997. Scientists are still keeping the faith. Nature 386, 435-436.

Larson, E.J., Witham, L., 1998. Leading scientists still reject God. Nature 394, 313

Lewin, R., 1999. Complexity: life at the edge of chaos, Second edition. University of Chicago Press, Chicago, London.

Malley, B., 1995. Explaining order in religious systems. Method \& Theory in the Study of Religion 7, 5-22.

Malley, B., 1997. Causal holism in the evolution of religious ideas: a reply to Pascal Boyer. Method \& Theory in the Study of Religion 9, 389-399.

Markússon, G.I., 2007. Book Review: Richard Dawkins (2006) The God delusion. Bantam Press, London. Journal of Cognition and Culture 7(2), 369-373.

Markússon, G.I. The salience and relevance of modern Icelandic Ásatrú: a preliminary case study in the immunology of culture. In: Geertz, A.W., Jensen, J.S. (Eds.), Religious

Narrative, Cognition and Culture: image and word in the mind of narrative. Equinox Publishing, London, in press.

Martin, M., 2007. The Cambridge Companion to Atheism. Cambridge University Press, Cambridge.

McGrath, A.E., 2004. The Twilight of Atheism: the rise and fall of disbelief in the modern world. Doubleday, New York.

McGrath, A.E., 2006. Dawkins' God: genes, memes, and the meaning of life. Blackwell Publishing, Malden.

McGrath, A.E., McGrath, J.C., 2007. The Dawkins Delusion? Atheist fundamentalism and the denial of the divine. Inter-Varsity Press, Downers Grove, Ill.

Mead, G.H., 1934. Mind, Self, and Society: from the standpoint of a social behaviorist. In: Morris, C.W. (Ed.). University of Chicago Press, Chicago reprint 1967.

Mills, D., 2006. Atheist Universe: the thinking person's answer to Christian fundamentalism. Ulysses Press, Berkeley.

Myers, P.Z., 2007. Letter to a non-atheist new atheist. Pharyngula October 5. http://scienceblogs.com/pharyngula/2007/10/letter_to_a_nonatheist_new_ath.php.

Nisbet, M.C., 2007a. The new atheism and a purpose driven life. Framing Science June 26. http://scienceblogs.com/framing-science/2007/06/the_new_atheism_and_a_ purpose.php.

Nisbet, M.C., 2007b. Why the atheist noise machine fails. Framing Science August 19. http://scienceblogs.com/framing-science/2007/08/why_the_new_atheist_attack_mac. php.

Orr, H.A., 2006. The God project. The New Yorker March 27. http://www.newyorker.com/printables/critics/060403crbo_books.

Paul, G., Zuckerman, P., 2007. Why the gods are not winning. Edge. The Third Culture. http://www.edge.org/3rd_culture/paul07/paul07_index.html.

Peirce, C.S., 1955a. Logic as semiotic: the theory of signs. In: Buchler, J. (Ed.), Philosophical Writings of Peirce. Dover Publications, New York, pp. 98-128.

Peirce, C.S., 1955b. Pragmatism in retrospect: a last formulation. In: Buchler, J. (Ed.), Philosophical Writings of Peirce. Dover Publications, New York, pp. 269-289.

Pyysiäinen, I., 2002. Ontology of culture and the study of human behavior. Journal of Cognition and Culture 2 (3), 167-181.

Pyysiäinen, I., 2003. How Religion Works: towards a new cognitive science of religion. Brill, Leiden.

Richerson, P.J., Boyd, R., 2005. Not by Genes Alone: how culture transformed human evolution. University of Chicago Press, Chicago.

Rosenhouse, J., 2006. Adler on atheism. EvolutionBlog September 8. http://scienceblogs.com/evolutionblog/2006/09/adler_on_atheism.php\#more. 
Rosenhouse, J., 2008. Nisbet says Myers and Dawkins hurt the cause: yawn. EvolutionBlog March 23. http://scienceblogs.com/evolutionblog/2008/03/nisbet_says_myers_ and_dawkins.php\#more.

Saler, B., Ziegler, C.A., 2006. Atheism and the apotheosis of agency. Temenos. Nordic Journal of Comparative Religion 42 (2), 7-41.

Schjødt, U., 2007. Homeostasis and religious behaviour. Journal of Cognition and Culture 7, 313-340.

Shastri, H.P., 1925. Lokāyāta. Dacca.

Shermer, M., 1997. Why People Believe Weird Things: pseudoscience, superstition, and other confusions of our time. Henry Holt and Company, New York

Solé, R., Goodwin, B., 2000. Signs of Life: how complexity pervades biology. Basic Books, New York.

Sosis, R., 2000. Religion and intragroup cooperation: preliminary results of a comparative analysis of utopian communities. Cross-Cultural Research 34 (1), 77-88.

Sosis, R., 2003. Why aren't we all Hutterites? Costly signaling theory and religious behavior. Human Nature 14 (2), 91-127.

Sosis, R., Alcorta, C., 2003. Signaling, solidarity, and the sacred: the evolution of religious behavior. Evolutionary Anthropology 12, 264-274.

Sosis, R., Bressler, E., 2003. Co-operation and commune longevity: a test of the costly signaling theory of religion. Cross-Cultural Research $372,11-39$.

Sosis, R., Kress, H., Boster, J., 2007. Scars for war: evaluating alternative signaling explanations for cross-cultural variance in ritual costs. Evolution \& Human Behavior 28, 234-247.

Sperber, D., 1985. Anthropology and psychology: towards an epidemiology of representations. The Malinowski memorial lecture, 1984. Man N.S 20, 73-89.

Sperber, D., 1996. Explaining Culture: a naturalistic approach. Blackwell Publishers, Oxford.

Sperber, D., 2000. An objection to the memetic approach to culture. In: Aunger, R. (Ed.), Darwinizing Culture: the status of memetics as a science. Oxford University Press, Oxford, pp. 163-173.

Stenger, V.J., 2007. God: the failed hypothesis. How science shows that God does not exist. Prometheus Books, Amherst.

Thrower, J., 1980. The Alternative Tradition: religion and the rejection of religion in the ancient world. Mouton, The Hague.

Tomasello, M., 1999. The Cultural Origins of Human Cognition. Harvard University Press, Cambridge, MA.

Tooby, J., Cosmides, L., 1992. The psychological foundations of culture. In: Barkow, J.H., et al. (Eds.), The Adapted Mind: evolutionary psychology and the generation of culture. Oxford University Press, New York, pp. 19-136.

Tucci, G., 1924. Linee di una storia del materialismo indiano. In: Atti della Reale Accademia Nazionale dei Lincei. Tip. Della R. Accademia nazionale dei Lincei, Rome, pp. 242310. Reprinted in Tucci's collected works Opera Minora. G. Bardi, Rome, vol. 1, 49-132.

Turner, J., 1985. Without God, Without Creed: the origins of unbelief in America. Johns Hopkins University Press, Baltimore.

de Waal, F., 2006. Primates and Philosophers: how morality evolved. Princeton University Press, New Jersey.

Werneken, F., Tomasello, M., 2009. Varieties of altruism in children and chimpanzees. Trends in Cognitive Sciences 13 (9), $397-402$.

Whitehouse, H., 2004. Modes of Religiosity: a cognitive theory of religious transmission. AltaMira Press, Walnut Creek.

Whitehouse, H., 2008. Cognitive evolution and religion: cognition and religious evolution. In: Bulbulia, J., et al. (Eds.), The Evolution of Religion: studies, theories, \& critiques. Collins Foundation Press, Santa Margarita, pp. 31-41.

Wieseltier, L., 2006. The God genome. The New York Times February 19. http://www.nytimes.com.

Wilson, D.S., 2002. Darwin's Cathedral: evolution, religion, and the nature of society. University of Chicago Press, Chicago.

Wilson, D.S., 2007a. Beyond demonic memes: why Richard Dawkins is wrong about religion. ESkeptic. The Email Newsletter of the Skeptic Society July 4. http://www.skeptic. com/eskeptic/07-07-04.html.

Wilson, D.S., 2007b. Atheism as a stealth religion. The Huffington Post December 14. http://www.huffingtonpost.com/david-sloan-wilson/atheism-as-a-stealth-reli_b_76901. html.

Wolf, G., 2006. The Church of the Non-believers. Wired November. http://www.wired.com/wired/archive/14.11/atheism.html.

Zuckerman, P., 2007. Atheism: contemporary numbers and patterns. In: Martin, M. (Ed.), The Cambridge Companion to Atheism. Cambridge University Press, Cambridge, pp. 47-65.

Armin W. Geertz is Professor in the History of Religions at the Department of the Study of Religion, Faculty of Theology, Aarhus University (AU), Denmark. His research areas include cognitive theory in the study of religion; the interface between cognition and culture; the religions of indigenous peoples; recent developments in contemporary religiosity; and method and theory in the comparative study of religions. He was chair of the two-year research project "Religious Narrative, Cognition and Culture" and is currently chair of the research unit project "Religion, Cognition and Culture (RCC)". He is founding member and Secretary General of the International Association for the Cognitive Science of Religion (IACSR); Project Partner in the EU 7th Framework project "Explaining Religion" and member of the board of MINDLab at Aarhus University. He is the author of over 300 publications.

Guð̃mundur Ingi Markússon holds a Cand. Mag. degree in the study of religion from Aarhus University, Denmark. His interests include the significance of religious information and signals as social markers (a pilot project with Human Behavior Laboratory, University of Iceland); Western esotericism; contemporary religiosity; atheism; evolutionary psychology and its limits; gene-culture co-evolution; biosemiotics, especially the "rehabilitation" of memetics through Peircian semiotics (in the work of T.W. Deacon) and the significance of semiotic ecologies for cultural evolution; Darwinism in the humanities and social sciences. He is a member of the Reykjavik Academy, association of independent scholars, in Reykjavik, Iceland, and a member of the International Association for the Cognitive Science of Religion (IACSR). 